\title{
STUDI PENERAPAN ALAT POTONG KAIN MEKANIS UNTUK KELOMPOK KERAJINAN TANGAN DARI BAHAN KAIN FLANEL KELURAHAN METESEH KECAMATAN TEMBALANG SEMARANG
}

\author{
Berlian Arswendo Adietya ${ }^{1}$, Atiek Suprapti \\ Aulia Windyandari ${ }^{1}$, Hartono ${ }^{1}$
}

\author{
${ }^{1}$ Departemen Teknik Perkapalan, Fakultas Teknik, Universitas Diponegoro \\ Jl. Prof. Soedarto, SH, Kampus Undip Tembalang, Semarang, Indonesia 50275 \\ ${ }^{2}$ Departemen Teknik Arsitektur, Fakultas Teknik, Universitas Diponegoro \\ Jl. Prof. Soedarto, SH, Kampus Undip Tembalang, Semarang, Indonesia 50275
}

Email: berlianarswendokapal@gmail.com

\begin{abstract}
ABSTRAK
Berdasarkan hasil observasi di lapangan dan diskusi dengan kelompok pengrajin flanel yang tergabung dalam UKM "Toko Ijo Asesoris" yang berlokasi di Bukit Kencana Jaya, Kelurahan Meteseh, Kecamatan Tembalang, Semarang mengakui adanya beberapa persoalan yang dihadapi dikalangan pengrajin flanel yaitu: terjadinya ketidakakuratan dalam proses pemotongan dengan menggunakan gunting, sehingga menyebabkan banyak bahan flanel yang terpaksa harus dibuang atau dimanfaatkan untuk sesuatu menurunkan nilai produk.

Upaya peningkatan produktivitas melalui pengembangan dan penerapan alat potong kain mekanik untuk bentuk pola akan menjadi fokus penelitian ini. Penerapan alat potong mekanik diharapkan dapat meningkatkan kecepatan potong dan menurunkan kesalahan akibat pemotongan secara manual dengan menggunakan gunting khusunya bagi pengrajin pemula.
\end{abstract}

Kata kunci: Kerajinan kain flanel, Peralatan potong mekanik mekanik

\begin{abstract}
Based on observations in the field and discussions with groups of artisans flannel incorporated in UKM "Toko Ijo Accessories" located in Bukit Kencana Jaya, Village Meteseh, District Tembalang, Semarang recognizes some problems encountered among craftsmen flannel namely: the occurrence of inaccuracies in the cutting process using scissors, causing a lot of flannel material that had to be discarded or used for something down the value of the product. Efforts to improve productivity through the development and application of mechanical cutting tools will be the focus of this study. The application of mechanical cutting tools is expected to increase the cutting speed and decreases errors due to manual cutting with scissors artisans especially for beginners.
\end{abstract}

Key words: Flannel handycrafts, mechanical cutting tools. 


\section{PENDAHULUAN}

Kegiatan produksi kerajinan tangan flanel di Indonesia saat ini cukup berkembang. Di berbagai kota telah bermunculan pengrajin-pengrajin flanel yang mulanya berawal dari hobi kemudian berkembang menjadi sebuah usaha kecil yang mampu menghasilkan pendapatan tambahan bagi keluarga. Tumbuhnya kelompok-kelompok pengrajin flanel ini, haruslah di dukung perkembangannya agar mampu meningkatkan aktivitas ekonomi yang dapat berdampak terhadap terbukanya peluang kerja sampingan dan pendapatan tambahan.

UKM "Toko ijo asesoris" dan kelompok binaan-nya "Flanel Meteseh" yang menjadi mitra dalam kegiatan ini berada di wilayah Bukit Kencana Jaya, Kelurahan Meteseh, Kecamatan Tembalang, Semarang. UKM "Toko ijo asesoris" dalam hal ini sebagai mitra pertama yang sudah memiliki pengalaman dalam memproduksi kerajinan kain flanel yang dijual di pasaran, sedangkan mitra kedua adalah Kelompok Binaan dari UKM "Toko ijo asesoris" yaitu "Flanel Meteseh" yang beranggota para pengrajin-pengrajin pemula kain flanel.

UKM "Toko ijo asesoris" memulai usahanya pada tahun 2007 berlokasi di Bukit Kencana Jaya, Kelurahan Meteseh, Kecamatan Tembalang. Produk-produk kerajinan flanel yang telah dihasilkan beraneka ragam, antara lain: baju dan kaos anak-anak, gantungan kunci, sandal dan berbagai pernak-pernik lainnya. Produk andalan "Toko ijo asesoris" ini adalah macammacam aplikasi hiasan jahit yang biasa digunakan sebagai hiasan baju, kaos maupun pakaian lainnya seperti mukena dan jilbab. Produk-produk kerajinan tangan flanel dapat dilihat pada Gambar 1.

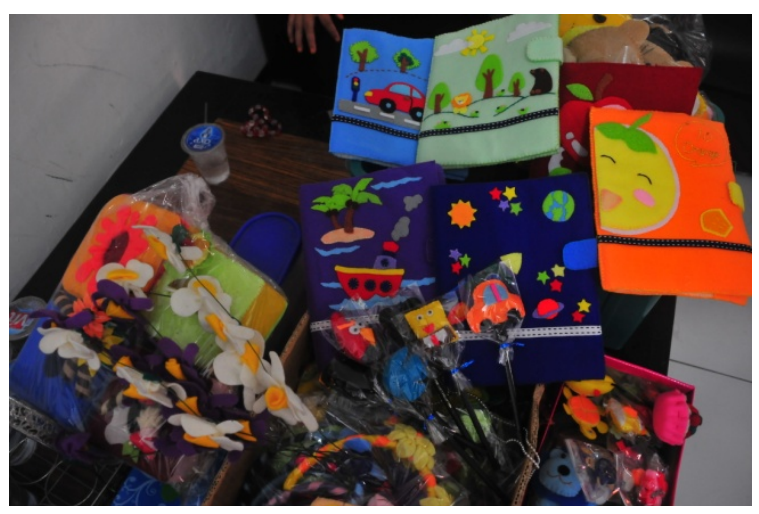

Gambar 1. Produk-produk dari bahan flanel dari UKM'Toko ijo asesoris"

Proses produksi kerajinan flanel yang dilakukan oleh UKM "Toko ijo asesoris" dimulai dari proses pekerjaan perencanaan gambar desain pola/mal. Pola / mal yang sudah dibuat, kemudian dijadikan sebagai cetakan untuk memotong kain flanel. Proses penataan mal di atas kain disebuat juga sebagai proses nesting. Penataan posisi pola pada proses nesting haruslah diatar sedemekian rupa hingga bahan flanel yang terbuang tidak banyak. Setelah itu dilanjutkan ke proses cutting, (pemotongan). Proses pemotongan biasa dilakukan seperti halnya proses pemotongan pada pekerjaan menjahit, yaitu menggunakan gunting potong sebagai alat potong. Setelah dilakukan pemotongan kemudian dilakukan proses perakitan yaitu menggunakan lem ataupun dengan dijahit. Pemasangan komponen-kompenen lain seperti ring gantungan kunci, tali kait untuk handphone dirakit secara bersama-sama pada proses perakitan. Pada proses perakitan terdapat beberapa teknik mengolah komponen dasar menjadi beberapa komponen objek kerajinan. Ketrampilan ini yang menjadi bekal utama bagi pengrajin flanel. 
UKM “Toko ijo asesoris" selain memproduksi kerajinan tangan flanel, juga terlibat dalam penjualan dan pemasaran produk-produknya. Pemasaran produk-produk UKM "Toko ijo asesoris" masih bersifat tradisional yaitu dengan memasukkan barang-barang hasil produksi ke pedagang-pedagang pasar ataupun toko-toko pernak-pernik. Namun tak sedikit pula order yang bersifat pesanan sesuai dengan kebutuhan pelanggan, misalnya untuk souvenir ulang tahun, pernikahan ataupun hajatan yang lain. Aktivitas produksi kerajinan flanel di UKM “Toko ijo asesoris" dapat dilihat pada Gambar 2.

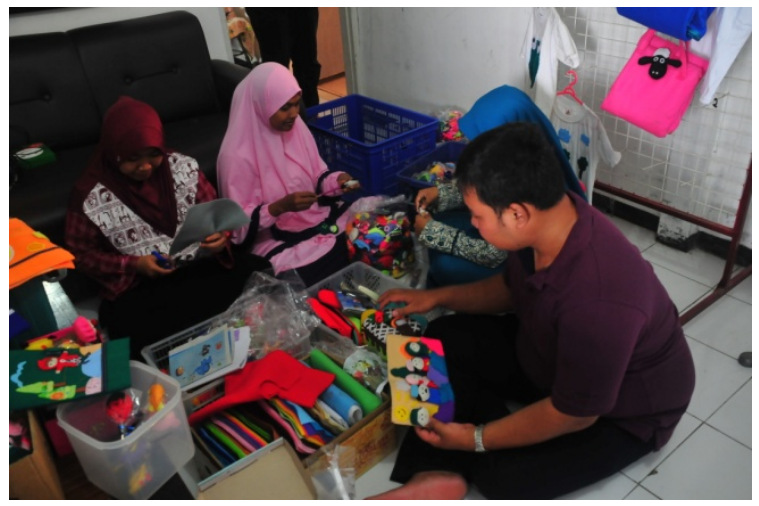

Gambar 2. Kegiatan pada UKM "Toko ijo asesoris"

Luaran yang dihasilkan dari penelitian ini adalah berupa produk peralatan potong flanel yang digunakan untuk memotong bahan flanel dengan memiliki bentuk pola khusus seperti: bentuk hello kitty, angry bird, buah-buahan dan berbagai macam desain pola flanel. Secara teoritis perancangan peralatan potong haruslah memperhatikan karakter jenis kain yang akan dipotong. Nilai susut dimensi kain akibat proses pemotongan juga harus diperhitungkan, sehingga ukuran hasil potong benar-benar presisi dan akurat sesuai yang diharapkan.

UKM “Amber Biru" dan kelompok binaan-nya "Ambar Bulusan" yang menjadi mitra dalam kegiatan ini berada di wilayah Kelurahan Tembalang, Kecamatan Tembalang, Semarang. UKM “Amber Biru" dalam hal ini sebagai mitra pertama yang sudah memiliki pengalaman dalam memproduksi kerajinan perhiasan dari batu ambar, sedangkan mitra kedua adalah Kelompok Binaan dari UKM "Amber Biru" yaitu "Ambar Bulusan" yang beranggota para pengrajin-pengrajin pengolahan batu akik dan batu ambar.

UKM “Amber Biru” memulai usahanya pada tahun 2010 berlokasi di Tembalang Regency, Kelurahan Tembalang, Kecamatan Tembalang. Tidak seperti produsen-produsen batu akik pada umumnya, "Amber Biru" memiliki ciri khas produk berupa produk-produk kerajinan yang terbuat dari batu ambar. Batu ambar tersebut diolah dirakit menjadi beberapa produk yang berupa kalung, liontin, tasbih, gelang ataupun produk kerajinan yang sejenis.

\section{TINJAUAN PUSTAKA}

Kain flanel atau felt adalah jenis kain yang dibuat dari serat wol, tanpa ditenun. Proses pembuatan kain flanel disebut juga wet felting, yaitu proses pemanasan dan penguapan sehingga menghasilkan jenis kain flanel atau felt yang beragam tekstur dan jenisnya, tergantung dari campuran bahan pembuatnya, (lihat Gambar 3). Flanel merupakan jenis kain tertua dalam sejarah manusia, lebih tua dari kain tenun dan rajut. Jenis kain flanel yang 
sangat rumit juga ditemukan dalam kondisi diawetkan di sebuah makam di Siberia yang berasal dari tahun $600 \mathrm{M},[1]$.

Banyak bangsa yang memiliki legenda dalam kebudayaannya tentang pembuatan kain felt atau flanel ini. Legenda dari Sumeria mengklaim bahwa pembuatan flanel untuk pertama kalinya ditemukan oleh seseorang yang bernama Urnamman, [2]. Tradisi membuat kain felt juga masih dipraktikan oleh kaum nomadic di Asia Tengah untuk membuat permadani, tenda atau pakaian. Di Barat flanel juga digunakan secara luas sebagai media untuk berekspresi dalam dunia seni tekstil seperti halnya seni desain.

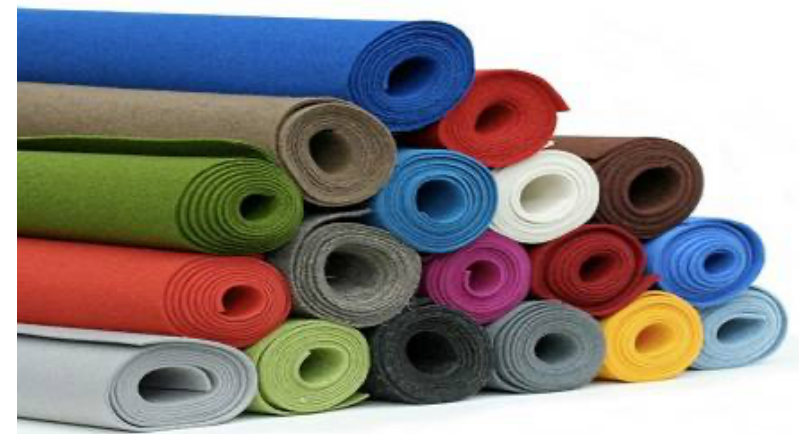

Gambar 3. Kain Flanel dengan berbagai pilihan warna

Kain flannel dalam sejarah sudah melintas di berbagai negara. Hal ini juga menyebabkan adanya penyebutan yang berbeda ditiap negara yang menggunakan kain ini. Orang-orang eropa menyebutnya flannelette, orang perancis menyebutnya flanelle, dan dalam bahasa inggris biasa disebut Felt yang berasal dari kata "wet felting", [3]. Penggunaan kain flannel di Indonesia banyak ditemui di berbagai industri, antara lain: industri otomotif, industri musik dan industri fashion.

Pada industri otomotif bahan flannel digunakan pada kendaraan mobil. Penggunaan flannel pada produk mobil digunakan sebagai pelindung bagian bawah mobil. Flanel juga digunakan sebagai peredam getaran antara panel interior dengan sumber getar yang berada di ruang mesin. Sering kali kain flannel juga digunakan sebagai pencegah kotoran agar tidak masuk. Kelebihan inilah bahan flannel sering dipakai dalam industri otomotif.

Pada industri musik, bahan flannel juga sering dipakai, contohnya dipakai sebagai tatakan cymbal drum. Bahan flannel mencegah terjadinya retak dan memastikan suara cymbal dapat diproduksi dengan baik. Flanel digunakan juga untuk membungkus bass drum dan pemukulnya agar menghasilkan bunyi jernih dan bersih. Pada alat musik piano, palu piano terbuat dari kain flanel yang berada disekitar kayu inti. Kepadatan dan sifat pegas dari flanel adalah bagian utama dari penciptaan nada piano. Pada akordion, flanel ditempatkan dibawah tuts piano akordion untuk mengontrol sentuhan dan bunyi.

Kain flanel adalah kain tenun lembut dan halus, yang terbuat dari wol, katun atau serat sintetis. Kain flanel telah lama digunakan sebagai bahan dasar pembuatan pakaian. Pada industri fashion modern, kain flanel tidak hanya digunakan sebagai baju, tetapi berbagai produk fashion juga banyak menggunakan bahan flanel seperti: topi, sepatu, tas, dompet, dan sebagainya. 
Seiring berjalannya waktu, flanel semakin di kenal banyak orang. Terutama, kalangan perajin aksesori. Aneka kerajinan tangan dari flanel bisa bermacam - macam, antara lain: gantungan kunci, gantungan handphone, tempelan kulkas, bross krudung, jepitan rambut, kalung, bando dan sebagainya. Kain flanel dapat di temui di toko-toko perlengkapan jahit. Salah satu hal yang menarik dari kain flanel adalah warnanya yang beragam dan lengkap, selain itu tekstur kainnya yang lembut. Tekstur yang lembut membuat kain flanel aman bagi anak-anak, bila digunakan sebagai bahan mainan.

\section{BAHAN DAN METODE}

Pada pekerjaan pemotongan kain, sebelum memotong kain perlu diketahui jenis-jenis alat dan mesin yang diperlukan untuk memotong kain, sehingga dalam memotong kain akan dihasilkan komponen-komponen kerajinan tangan flanel yang sesuai dengan standar kualitas order dan mempunyai ukuran dan bentuk komponen yang tepat. Peralatan potong kaian pada industri garmen terdiri dari: straight cutter, rotary cutter, band knife, die cutting press dan laser knife, [5]. Masing-masing jenis alat potong tersebut memiliki fungsi dan kegunaan sesuai kebutuhan pengguna.

Mesin potong dengan pisau lurus atau vertikal ( Straight Cutter) adalah mesin potong yang mempunyai mata pisau berbentuk satu lembar plat baja lurus dan pada waktu memotong mata pisau tersebut bergerak naik turun (dua arah ). Ukuran panjang mata pisau antara 5-14 inci. Alat ini digunakan untuk memotong susunan kain yang cukup tinggi . Ketinggian susunan kain disesuaikan dengan panjang pisau dan kapasitas mesin potong.

Mesin potong dengan pisau bundar ( Rotary /Round Cutter ) adalah mesin potong yang mempunyai mata pisau berbentuk piringan, pada waktu memotong mata pisa bergerak memutar pada as ke satu arah ( ke depan ). Ukuran diameter pisau potong adalah 2,5-10 inci. Alat ini digunakan untuk memotong kain dengan tumpukan yang tidak tinggi karena terbatas dengan ukuran diameter pisau potong, maksimum tinggi tumpukan kain adalah setengah dari diameter pisai yang dipakai.

Mesin potong dengan pisau pita atau lembaran ( Band Knife ) adalah mesin potong yang mempunyai mata pisau berbentuk pipih/pita pada kedua ujungnya menyambung/melingkar, sehingga gerak mata pisau waktu memotong adalah melingkar kesatu arah, dan untuk menggerakkan mata pisau tersebut dikontrol oleh beberapa roda penggerak yang juga berfungsi untuk menjaga ketegangan lembaran mata pisau. Jadi mata pisaunya bergerak statis satu arah, sehingga proses pemotongan terlaksana dengan mendorong kain yang akan dipotong kearah mata pisau yang terus berputar, pengguna tinggal menggerakkan tumpukan kain sesuai bentuk pola / marker yang akan dipotong. Band knife biasa digunakan untuk memotong bagian - bagian yang sulit dan banyak lengkungan.

Mesin potong cetak ( Die Cutting Press ) adalah mesin potong yang mempunyai mata pisau berbentuk pola komponen yang akan dipotong dan digerakkan secara hidrolik. Alat ini digunakan untuk memotong komponen tertentu yang memerlukan ketelitian tinggi, misalnya: kerah, kantong, klep, manset, pola aplikasi hiasan baju dan sebagainya.

Laser Knife adalah mesin potong otomatis generasi terbaru yang sistem dan cara kerjanya adalah :

- Pola/marker garmen yang akan diproduksi direkam dengan sistem CAD/CAM. 
- Hasil rekaman marker dipindahkan ke mesin potong yang telah diletakkan diatas meja potong dengan posisi kain siap untuk dipotong.

- Mesin potong secara automatis akan bergerak sesuai dengan marker yang telah diprogram dengan sistem CAD / CAM.

Mesin ini memancarkan sinar laser yang besarnya $0,1 \mathrm{~mm}$ dengan hasil pemotongan kain dijamin akurat sesuai bentuk dan ukuran pola. Pada proses pemotongan dengan sinar laser ini sama sekali tidak terjadi pergeseran atau tekanan pada bidang- bidang kain seperti pada mesin potong konvensional.

Upaya peningkatan produktivitas dalam kegiatan pengrajin flanel di lingkungan UKM Toko Ijo Asesoris akan menjadi fokus penelitian ini. Pengurangan jumlah rework dan terbuangnya material akan dicapai melalui beberapa target-target luaran yang terdiri dari:

- Alat prototipe potong mekanik yang dapat memberikan hasil potong pola secara presisi akurat dan cepat, khususnya untuk memotong bahan flanel.

- Peningkatan produktivitas melalui penerapan alat potong mekanik yang diusulkan dapat dicapai dengan meningkatkan kecepatan potong dan menurunkan kesalahan akibat pemotongan secara manual.

- Kondisi proses pemotongan pola yang mudah dan cepat diharapkan dapat meningkatkan produktivitas proses pembuatan kerajinan flanel dan kualitas mutu produk.

- Diperoleh suatu sistem operasi atau standar prosedur operasi untuk proses pembuatan kerajinan flanel di UKM Toko ijo asesoris.

- Diperoleh suatu analisis ekonomi dengan adanya penambahan peralatan potong mekanik.

- Diperoleh pemahaman pada pengrajin UKM Toko ijo asesoris, tentang penggunaan dan manfaat alat potong mekanik, sehingga dapat memanfaatkan fungsi peralatan potong dengan benar dan maksimal.

Metode penelitian yang digunakan pada program ini diawali dengan melakukan evaluasi terhadap proses produksi kerajinan flanel pada UKM "Toko Ijo Asesoris" di Bukit Kencana Jaya, Kelurahan Meteseh, Kecamatan Tembalang, Semarang. Berdasarkan dari hasil survei awal tersebut, kemudian ditentukan tahapan-tahapan pelaksanaan kegiatan pengabdian masyarakat ini. Tahapan-tahapan pelaksanaan kegiatan tersebut dinyatakan dalam diagram alir yang dapat dilihat pada Gambar 4.

\section{HASIL DAN PEMBAHASAN}

\section{Desain mesin press untuk para pengrajin flanel}

Pada tahapan ini telah dikembangkan desain mesin press untuk para pengrajin flanel. Desain mesin press disesuaikan dengan kebutuhan pengrajin flanel dalam memotong bermacammacam jenis pola secara presisi dan akurat. Selain berdasarkan kemampuan alat cepat dalam memotong dan presisi juga dilengkapi dengan beberapa variasi motif sehingga produk flanel yang dihasilkan beragam sesuai dengan permintaan pasar. Mesin press memiliki ukuran kecil dan sederhana sehingga pengoperasian lebih mudah dan resiko terhadap terjadinya cidera sangat kecil.

\section{Pengadaan mesin jahit pinggir dan pendampingan ke pada UKM sasaran}

Desain yang telah dikembangkan selanjutnya dilakukan pembuatan. Pada proses pembuatan mesin press dilakukan oleh tenaga-tenaga terlatih dan terampil sehingga produk yang dihasilkan benar-benar sesuai dengan desain yang telah dikembangkan. Tingkat kemajuan dari proses pembuatan masih pada tahapan pencarian bahan dan alat untuk membuat mesin 
press seperti tampak pada Gambar 5 Hal ini disebabkan karena teknisi tidak bisa melakukan kegiatan pembuatan alat karena terbentur liburan hari raya.

Pengadaan mesin jahit kepada UKM sasaran telah dilakukan, tidak hanya melakukan pengadaan juga dilakukan pengawasan, pendampingan dan pelatihan jahit pinggir kepada UKM sasaran, sehingga sesuai dengan prosedur penggunaan alat dan menghindari kesalahan yang timbul akibat pekerjaan yang diborongkan.

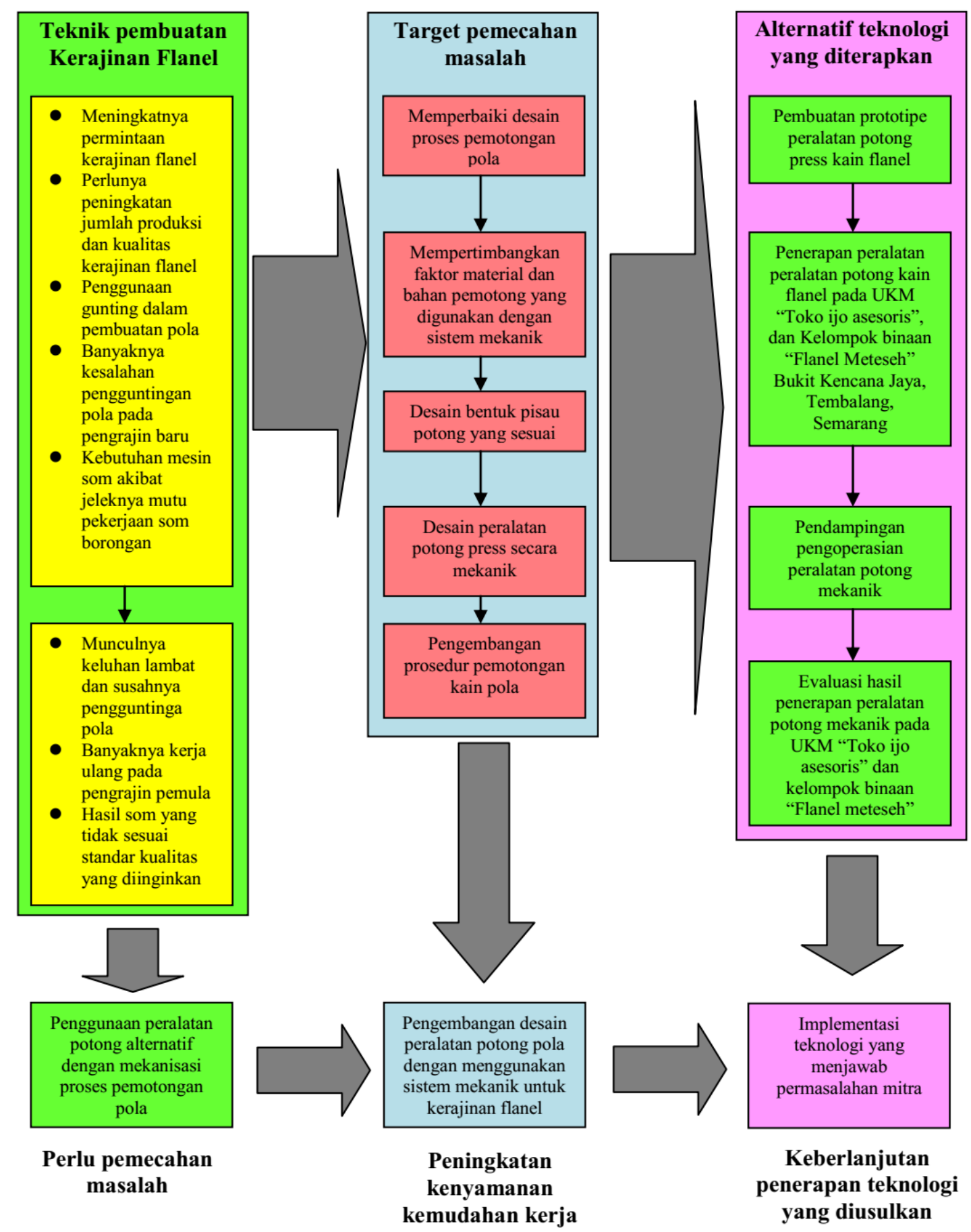

Gambar 4. Diagram alir metode pelaksanaan kegiatan penelitian 
Pada tahapan ini telah dikembangkan desain alat polishing bagi para pengrajin batu ambar. Desain alat polishing disesuaikan dengan kebutuhan pengrajin batu ambar dalam memoles batu ambar. Alat ini memiliki bagian yang berputar terus menerus dan bagian ini sudah dilapisi oleh serbuk intan, bagian ini berguna sebagai tempat memoles batu. Alat ini mempunyai kelebihan dibanding dengan polishing manual, lebih cepat dan dapat meminimal kerusakan pada batu ambar. Sifat batu ambar yang mudah pecah dan mudah tergores mengakibatkan banyak masalah pada saat memoles dengan cara manual. Dengan adanya alat polishing masalah tersebut dapat dihindarkan karena pengrajin batu ambar dapar mengontrol kecepatan putar alat sesuai dengan kebutuhan pemolesan.

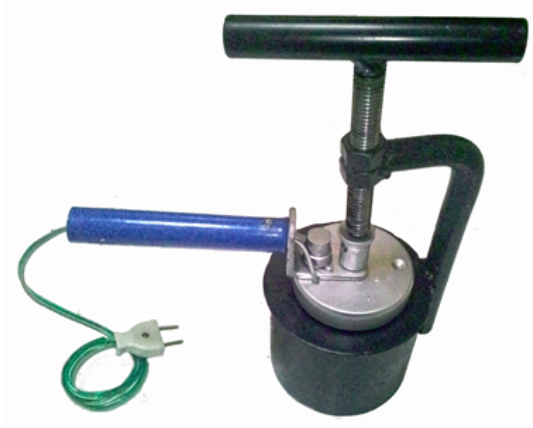

Gambar 5. Desain mesin press untuk para pengrajin flanel

Pada pengembangan desain alat polishng lebih mengutamakan pada kemampuan dan kontrol alat dalam berputar sehingga mudah dilakukan proses pemolesan oleh pengrajin batu ambar. Desain polishing tidak berhubungan langsung terhadap potensi terjadinya cidera pada pengrajin batu ambar, namun lebih ditekankan pada kebutuhan panjang dan ketinggian untuk meletakkan batu ambar yang sedang poles pada proses polishing.

\section{Penambahan cutting pada mesin press portable}

Pada tahap berikutnya akan dilanjutkan pembuatan alat serta pemasangan pisau cutting pada alat, sehingga produk menjadi lebih nyaman dan cepat dalam melakukan aktifitas pada proses pemotongan. Setelah itu proses finishing dilakukan pada mesin press portable. Proses ini dilakukan agar produk yang dihasilkan memenuhi kualitas yang diharapkan oleh pengguna produk yaitu para pengrajin flanel. Selain merapikan produk, proses finishing juga membantu melindungi produk agar lebih awet dan tahan lama.

\section{Penerapan produk yang telah dikembangkan pada UKM mitra}

Produk peralatan jahit pinggir dan mesin potong kain flanel selanjutnya diberikan kepada mitra UKM agar digunakan oleh para pengrajin mebel di tempat kerjanya. Pendampingan pada penerapan produk dilakukan agar produk yang dihasilkan sesuai dengan prosedur penggunaan produk. Selain itu pada proses pendampingan juga dilakukan umpan balik dari pengguna produk untuk perbaikan dan masukan bagi perancang produk.

Berdasarkan pengamatan dan hasil wawancara yang dilakukan oleh tim pengabdian, peralatan jahit dan mesin potong flanel yang dikembangkan untuk perbaikan sistem produksi kerajinan flanel telah menunjukkan hasil perubahan yang baik, lihat Tabel 1. Para pengrajin 
flanel merasa bahwa dengan peralatan jahit dan mesin potong flannel ini dapat menerima order kerajinan flannel yang lebih banyak dan menghasilkan kualitas jahit pinggir yang sesuai dengan keinginan, sehingga pendapatan pengrajin semakin lebih baik. Adapun desain dan hasil akhir peralatan jahit dan mesin potong flanel yang dikembangkan adalah sebagai berikut, Gambar 6:
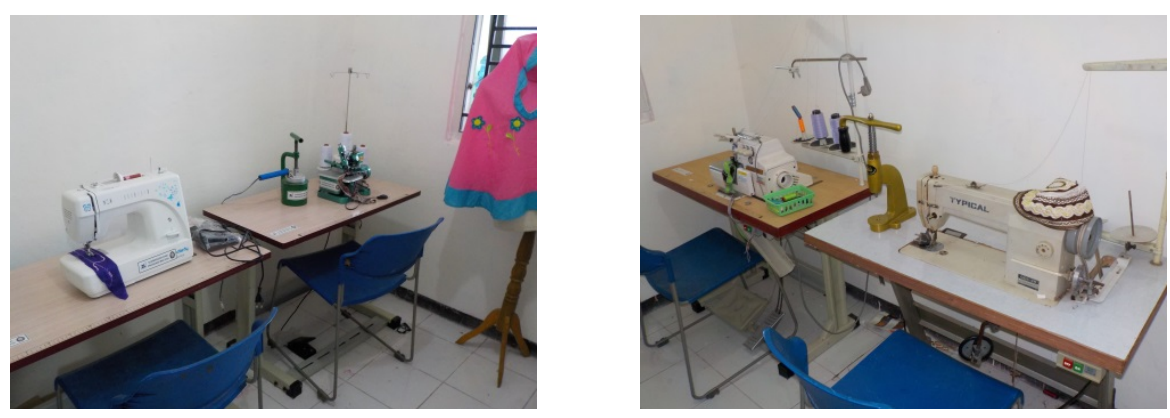

Gambar 6. Penerapan produk peralatan jahit dan mesin potong pada UKM "Toko Ijo Asesoris"

Tabel 1. Perubahan akibat penerapan alat polishing

\begin{tabular}{c|lccc}
\hline No & \multicolumn{1}{|c}{ Uraian } & $\begin{array}{c}\text { Sebelum } \\
\text { diaplikasikan }\end{array}$ & $\begin{array}{c}\text { Sesudah } \\
\text { diaplikasikan }\end{array}$ \\
\hline 1 & $\begin{array}{l}\text { Jumlah keluhan sulitnya memotong } \\
\text { bentuk pola secara presisi }\end{array}$ & 20 org/bulan & 5 org/bulan \\
2 & $\begin{array}{l}\text { Menurunnya jumlah perbaikan produk } \\
\text { reject akibat kesalahan proses } \\
\text { pemotongan oleh pengrajin baru }\end{array}$ & $\begin{array}{c}15 \\
\text { perbaikan/bulan }\end{array}$ & $\begin{array}{c}3 \\
\text { perbaikan/bulan }\end{array}$ \\
\hline
\end{tabular}

\section{KESIMPULAN}

Kegiatan studi penerapan alat potong kain mekanis untuk kelompok kerajinan tangan dari bahan kain flanel kelurahan meteseh kecamatan tembalang semarang telah dilaksanakan. Pengembangan desain sistem pelaksanaan jahit pinggir dan mesin potong flanel telah dikembangkan dan diaplikasikan pada UKM mitra. Hasil menunjukkan bahwa peralatan jahit dan mesin potong flanel telah memberikan peningkatan produktivitas khususnya pada proses produksi kerajinan flanel. Peningkatan kemampuan dalam proses penjahitan pinggiran dan pemotongan kain flanel yang ditawarkan mampu memperbaiki proses produksi kerajinan flannel serta mengurangi keluhan rendahnya kualitas produk kerajinan flannel akibat sering diborong oleh pihak ketiga. Peningkatan produktivitas dan peningkatan kualitas dapat dicapai dengan proses penjahitan pinggiran dan pemotongan bahan flanel di tempat mitra.

\section{DAFTAR PUSTAKA}

[1] Anonim, 2012. "Definisi kain flanel”, diakses dari situs azizah flanel (https://azizahflanel.wordpress.com/2012/06/05/definisi-kain-flanel/)

[2] Anonim, 2015. "Felt", diakses dari situs wikipedia http://en.wikipedia.org/wiki/Felt)

[3] Hilon, 2014. "Sejarah tentang kain felt". diakses dari situs hilon inside (http://www.hiloninside.com/blog/sejarah-tentang-kain-felt/)

[4] Emsosfi Zaini, 2010. "Model perencanaan pemotongan untuk meminimumkan jumlah 
pemotongan kain dan pemakaian kain”. Prosiding seminar nasional ritektra. ISBN: 978-602-97094-0-7

[5] Anti Asta Viani, 2003. "Teknik cutting sewing finishing". Bagian proyek pengembangan kurikulum direktorat pendidikan menengah kejuruan dirjen dikdasmen. 